\title{
A TRANSZEURÓPAI HÁLÓZATOK HATÁSA A TERÜLETI FEJLŐDÉSRE
}

\author{
(The Impact of the Trans-European Networks to the Spatial
} Development) ERDŐSI FERENC

\section{Bevezetés}

Európa egységének, belső kohéziójának megteremtésében és az országok, régiók közötti fejlettségbeli különbségek felszámolásában/csökkentésében az államhatárok közlekedési áramlásokat nehezitö, megtörö hatásainak megszüntetésében, a környezetterhelés mérséklésében és mindezek által földrészünk versenyképességének javításában az Európai Unió különleges szerepet szán a nemzetközi közlekedési, energiaszálítási és távkőzlési magisztrálékat magába foglaló, integrált kommunikációs rendszerré fejlesztenđö, az 1990-es évek elején kizárólag az Unió területére kidolgozott Transzeurópai Hálózatoknak (TEN = Transeuropean Network), valamint az 1989/91. évi kelet-európai politikai változások nyomán az Unión kívüli országokra is kiterjesztett Páneurópai Hálózatoknak (=PEN). Egyenlöre a két renđiszer önálló neveken szerepel a Közösség dokumentumaiban, de idővel várhatóan szervezetileg is egyetlen renđ̛szerré, "Összeurópai Hálózatokká" egyesül (Erdösi 1998b). Annak a kérdésnek, hogy e hálózatnak milyen hatásai várhatók a területi fejlödésre, természetesen európai léptékben, földrészünk területi szerkezetének alakulása szempontjából van elsösorban jelentösége, azonban számunkra ugyanilyen fontosak a várható hazai következményei is.

Azt az alapvető - korántsem csupán kommunikációs ágazati, de nem is kizárólag térszerkezeti, hanem a környezeti vonatkozásai miatt igazán releváns - kérdést azonban, hogy milyen mértékben szabad a forgalmat összpontositani és hogy a közlekeđés milyen alágazati szerkezete a legmegfelelöbb az európai társađalom elvárásainak, igazából teljességében mindmáig megválaszolatlan. E dolgozatban is csupán a területfejlesztés szempontjából igyekszünk bemutatni - a meglehetősen ellentmonđásos külfooldi szakértöi véleményeket egymással és a magunkéval szembesítve - a TEN céljai és a valódi hatásai közőtti ellentmonđásokat.

\section{A./ Az összeurópai hálózattól , hivatalosan” várt terület-és telepü- lésfejlesztô hatások}

A legfontosabb területfejlesztési célelképzeléseket is kielégitö és valamennyi közlekeđéshordozót szervesen integráló összeurópai rendszert még nem dolgoztak ki. E helyett (mintegy pótcselekvésként) a TEN-re elkészült 7 különböző alágazati fejlesztési irányelv (a közúti, vasúti, belvízi, tengeri és légi közlekedésröl, a kombinált szállításokról és a telekommunikációról), a PEN-re pedig 10 komplex korridort és 4 közlekedési területet állapítottak meg. (Ezekröl részletek Erdösi 1998a,b tanulmányaiban találhatók.) 


\section{A TEN területfejlesztési céljai}

A Transzeurópai Hálózatok koncepciója több éves folyamatban érlelödött ki és a róla időnkẻnt megjelentetett dokumentumokban meghirdetett célok között a mához közeledve nem elhanyagolható különbségek mutatkoznak. A célkitüzéseknek mindenképpen jelentỏs része - ha a kohéziós politika kereteibe ágyazva, áttételesen is a területfejlesztést is szolgálja, mégpedig az elérhetőség javításával a periférikus régiókban (a hiányzó összeköttetések megteremtésével, az elszigetelt ultraperiférikus területek - félszigetek, szigetek - elérhetőségének javításával, valamint az agglomerációk forgalmi tehermentesítésével, a forgalmi dugók megszuintetésével).

A TEN koncepcióját kiforrottabb állapotban bemutatók, az Európai Unió közlekedési magisztráléit tervezók (elsösorban a Christophensen-csoport) egyik érve, hogy a TEN elömozdítja a regionális gazdasági fejlödést, fellendíti a termelőtevékenységet az általa érintett térségekben, csökkenti a (központi és periférikus) régiók közötti különbségeket (Erdôsi 1997a)

A kőzlekedési irányelvekkel egyidőben a Területfejlesztési Bizottság (CSD) kidolgozta az európai területfejlesztés elsô tervezetét ("Egy európai területfejlesztési politika alapjai"). E dokumentum a TEN-nel szemben olyan területfejlesztési elvárásokat fogalmazott meg, mint

- a perifériális régiók helyzetének javítása,

- a közlekedési infrastruktúra közel egyenlő minöségủ elérhetőségének biztosítása,

- kơrnyezetbarát közlekedési hálózat kialakítása a közúti forgalom egy részének vasútra áthelyezésével,

- az értelmetlen mobilitás növekedésének megakadályozása, a felesleges közlekedés elkerülése (Kunze, E. 1995).

A dokumentum tájékoztató jelleggel és értékelés nélkül tartalmazza a Christophensen-csoport által prioritásra javasolt 4 projektet, de nem foglalkozik ezek megvalósításával.

Ezen az általános szinten a közlekedés- és területfejlesztési dokumentumok (közöttuk az 1995. évi "Európai Trendforgatókönyvek") hasonlitanak a TEN-re vonatkozó kérdések tekintetében. Egyrészt foglalkoznak a közlekedés területi problémáival (a nagy központok összekötésével, a perifériális régiók csatlakoztatásával, a TEN elérhetőségével), másrészt a környezetbarát, kisebb területigényũ közlekedés kialakításának céljaival, e szellemben a vasút elsőbbségével, a kőzúti szállítás vasútra átterelésével.

Az EU dokumentumok többé-kevésbé a "kincstári optimizmus" szellemében és nem kevés kővetkezetlenséggel íródtak.

A perifériák közlekedési feltártságbeli felzárkózási folyamatát alátámasztó prognózisszámitások eredményei

Egyes szakértői elemzések is (Gutierrez, $J$. 1996) megerösítik a Közösség dokumentumai által sugalmazott kedvező hatások bekövetkezését a periférikus térségekre nézve; sablonos számításaik a perifériák kơzlekedési ellátottságban való felzárkózását bizonyítják. 


\section{a) A TEN úthálózattal ellátottság alakulása}

Az úthálózat hosszának 1992-2002 közötti növekedési ütemét tekintve a legfigyelemreméltóbbak a periférikus fekvésủ országok várható eredményei (Írországban a 13-szorosára, Portugáliában a 4,5-szeresére, Görögországban a 2,2-szeresére bövül). A lakosságszámhoz mért (az 1 millió lakosra jutó $\mathrm{km}$ ) úthossz tekintetében a legkedvezöbb helyzetben 2002-re Spanyolország lesz (1. táblázat). A területre számított fajlagos mutató tekintetében viszont lényeges változás nem következik be a magtérségek és a perifériák között.

Az úthálózat további sürítésével lényegesen javul az elérhetöség 1992-2002 között, mert egyre nagyobb lesz az "útközeli" (40-40 km széles) sávok területének aránya az összterülethez képest (1-2. ábra) oly módon, hogy Görögország, Írország, az Ibériai-félsziget és Szardínia lesznek a legnagyobb haszonélvezői a fejlesztéseknek. Valamivel kisebb mértékben javul a helyzete Nagy-Britannia északi részének, Franciaország déli felének, Németország K-i részének és a Jütland-félszigetnek.

Az 1992. évi 69,9\%-kal szemben $J$. Gutierrez (1996) számításai szerint 2002-ben már az EU területének átlagosan a $84,9 \%$-át ölelik fel és a korábbinál jóval egyenletesebb területi megoszlásban a közúti folyosók. Így a jövö század elejére a perifériák "feljönnek", megközelítik a fejlett, törzsterületi országok feltártságát autópályákkal/gyorsforgalmi utakkal. (Feltáratlan "fehér" foltok akkor már csak az Ibériai félszigeten, Franciaország D-i részén - $\mathrm{pl}$. Korzikán -, Írország Ny-i részén fordulnak elö.)

\section{b) Európa föbb gazdasági központjainak elérhetösége}

Európa gazdaságilag fontos városainak a TEN-hez való viszonyát részben a magisztráléktól való fizikai távolságukra, részben GDP-termelésük nagyságára alapozó képlet segítségével határozták meg. Az 1992-2002 közötti tíz év alatt várható változások területi (vonzáskörzeti) ábrázolásban (3. ábra) egyértelmüen a földrajzi értelemben vett perifériák (a Brit-szigetek, az Ibériai-félsziget Ny-i része, Szardínia és Görögország) elönyére válnak.

Differenciáltabb, elemzésre alkalmasak a 94 európai közép- és nagyváros részletes adatai (melyek teljes körü bemutatásától terjedelmi okok miatt eltekintünk). Ezek alapján Nyugat-Európa viszonylagos értelemben továbbra is megörzi pozícióját: 2002-ben e városállományból a TEN által legjobban elérhetók a Benelux államok, Észak-Franciaország és Németország legnyugatibb részének sürün lakott agglomerációiban, elvárosiasodott régióiban, míg a legnehezebben elérhetōk Dél-Európa legfélreesóbb térségeiben (föként a szigeteken) lesznek - nem beszélve $a z$ ír és skót városokról.

c) Európa irányok és régiók szerint differenciält "zsugorodása" az elérhetöségi idók változásának eredményeként

Modern korunkban a tér-idő konvergencia nyomán az eljutás feltételeit már nem annyira km-hosszban, mint sokkal inkább az eljutáshoz, az utazáshoz szükséges időben mérjük. 


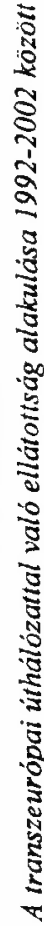

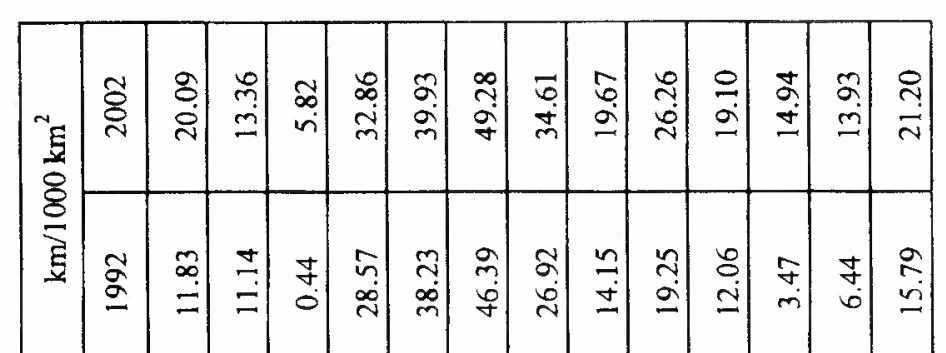

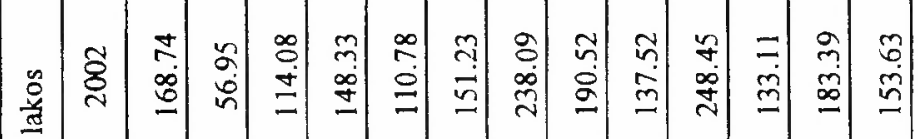

ฉั ธิ

:을

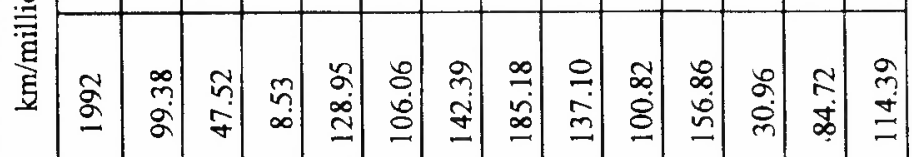

$\stackrel{2}{\alpha}$

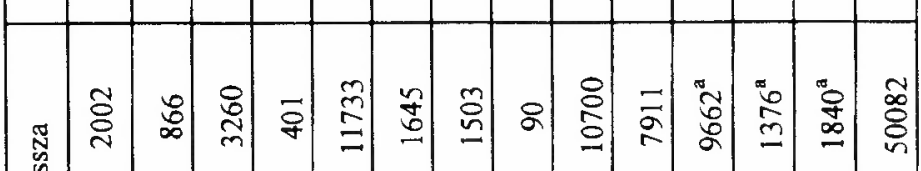

通 은

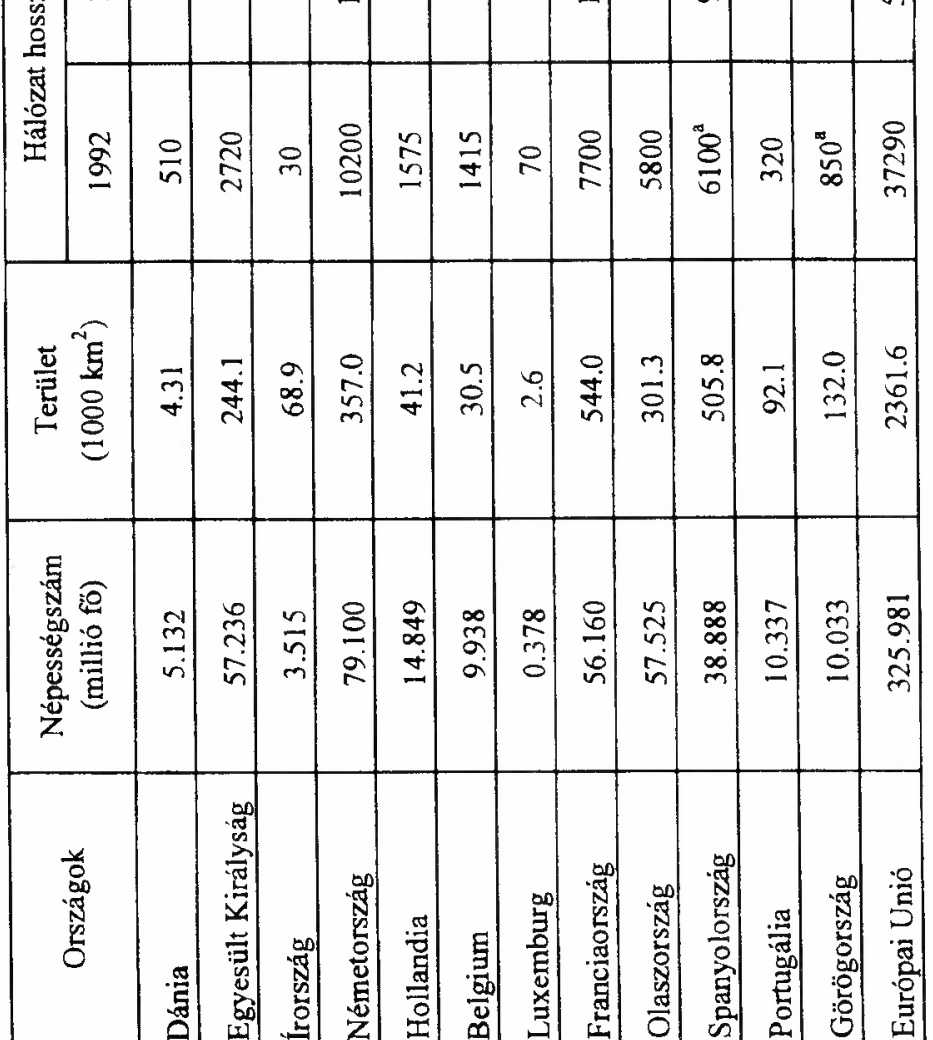




\section{1. ÁBRA}

A transz-európai útkorridorok kontaktzónái által lefedett területek 1992-ben (Areas covered by the corridors along the trans-European road network 1992)

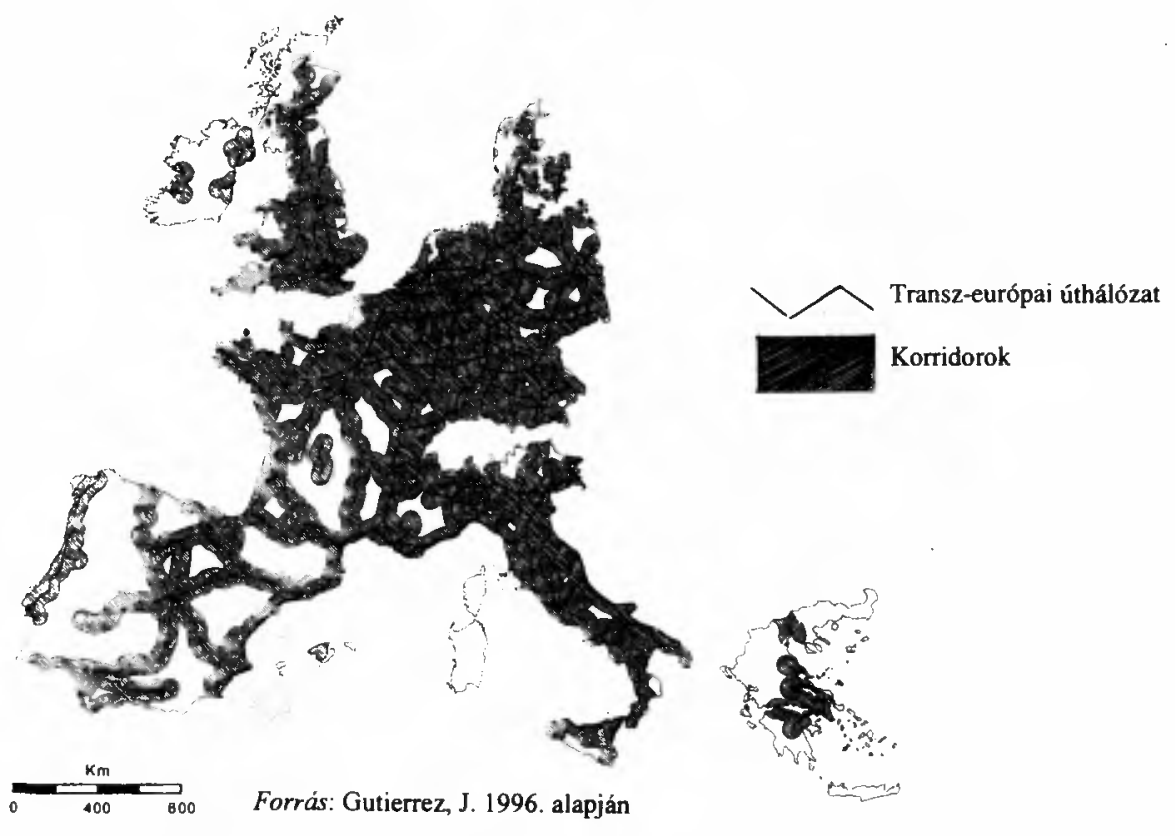

\section{2. ÁBRA}

A transz-europai útkorridorok kontaktzónái által lefedett területek 2002-ben (Areas covered by the corridors along the trans-European road network 2002)

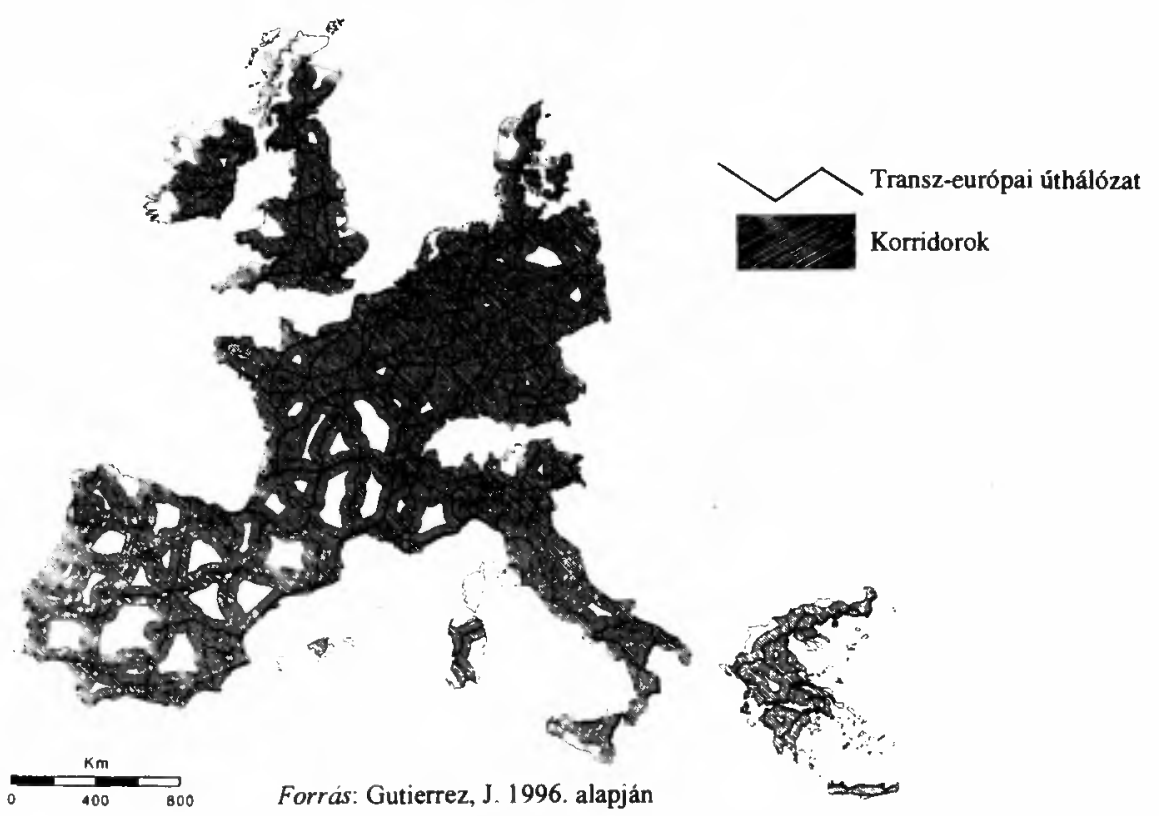




\section{3. ÁBRA}

Európa fö gazdasági központjai elérhetőségének változása, 1992-2002

(Changes in accessibility to the main economic activity centres in Europe 1992-2002)

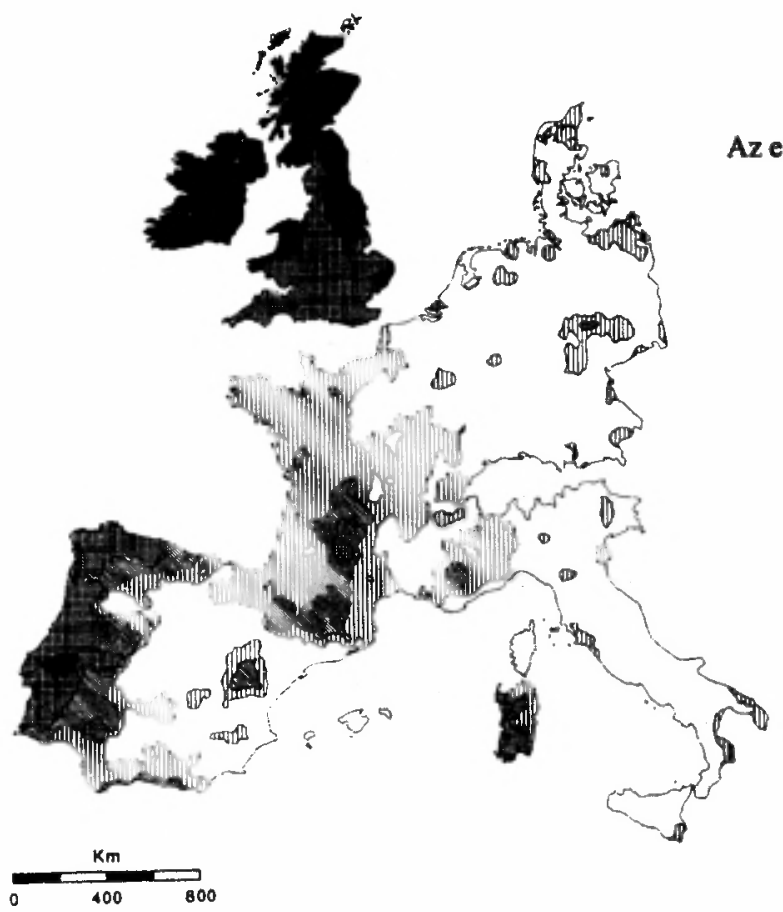

Az elérhetöség változása \%-ban

$\square 30$
$31-50$
$51-70$
$71-100$
$01-140$
$>140$

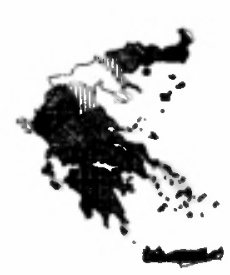

Forrás: Gutierrez, J. 1996. alapján 


\section{B. / A TEN valódi hatásai}

$\mathrm{Az}$ utóbbi években egyre több oldalról fogalmazódnak meg olyan vélemények, amelyek kisebb-nagyobb kételyeknek adnak hangot, vagy egyenesen kétségbe vonják a TEN-nek tulajdonított pozitív regionális hatásokat, de legalábbis rámutatnak arra, hogy az eredeti elképzelések szerinti megvalósitásának nemkivánatos következményei is lehetnek. Figyelemre méltóak azok a birálatok, amelyek az európai városhálózat szerkezet lehetséges/várható és kivánatos modelljének antinomiájába illesztik be a TEN kérdését. Mivel az utóbbi aspektusból a folyamat és a következmények végiggondolása társadalom-földrajzi (ezen belül település-földrajzi) szempontból is Európa egész térszerkezetét érintỏ alapvetö és izgalmas kérdéseket vet fel, ezért elöljáróban tísztáznunk kell néhány struktúraelméleti kérdést

\section{Elméleti megközelitések: a hálózatokban gondolkodás elsöbbségének szükségessége a hierarchiákkal szemben}

A tevékenységek és szervezetek hálózatok, valamint hierarchiák szerint strukturálódnak.

$\mathrm{Az}$ általános értelemben vett (területi infrastrukturális, társadalmi), egymásra ható hálózatok lehetőséget nyújtanak arra, hogy személyek, csoportok és szervezetek között kapcsolatok, összeköttetések jöjjenek létre. A hálózat tulajdonképpen a saját kezdeményezésből keletkező, szabadon végzett tevékenységek metaforája is, amely szemben áll a hierarchiák merev struktúrájával, képletével. Ezért a hálózatok és hierarchiák között rendszerint feszültségek keletkeznek.

A közösségi és magánszervezetek, de az államok és az Európai Közösség is egyaránt hierarchikus felépitésủek, mint ahogyan a területfejlesztésben sem ismeretlenek a hierarchiák. A tevékenységek sokrétúbbé válásával és területi elterjedésével növekszik a (természeti, gazdasági, társadalmi) környezet és a tevékenységi körök komplexitása, amely a konfliktusok megakadályozása érdekében megköveteli a lehetséges kétféle stratégia közüli választást.

A hierarchia primátusa azt jelenti, hogy vertikális összeköttetésekkel, több szabályozással és elóírással az összekapcsolódó folyamatokat áttekinthetó, formálisan ellenörizhetó pályára állítják. Ezzel szemben a hálózatok primátusa horizontális összeköttetéseken és önálló, innovatív tevékenységeken alapul. A piaci szabályozók is olyan tényezók, amelyek segítik a folyton változó feladatoknak megfeleló hálózatok létrejöttét és a hálózatok gazdasági múködtetését.

A két struktúra közül csupán az egyik vagy másik ("tiszta" stratégiaként) nemigen alkalmazható; a gyakorlatban inkább az egymáshoz való viszonyuk megállapítása fontos. Az egyiknek vagy a másiknak az elsőbbsége több dologtól, pl. attól is fúgg, hogy a területfejlesztésnek a jôvôben melyek lesznek a súlypontjai, a legfontosabb feladatai. 
A horizontális szervezetek hatásossága régóta ismert, gondoljunk csak a föderalizmus elvére, amit sikeresen érvényesítenek egyes államalakulatokban. De a sikeres multinacionális vállalatok is horizontálisan alakítják szervezetüket. Ez kevés hierarchiaszinttel és sok olyan teljesen önálló egység létezésével, müködtetésével jár, amelyek megteremtik a saját hálózatukat. Ezekben az esetekben tehát a hálózatok elsödlegessége érvényesül. Nagyon valószínü, hogy a hálózatokon belül a legtöbb innováció a hierarchiát "nem tisztelö" és a határokat átlépő folyamatokban keletkezik. Ez érvényes mind a tudományos kutatásra, mind a technikai-gazdasági újitásokra. A kifejezetten hierarchikus szervezetek kevésbé hajlamosak arra, hogy valami újat feltaláljanak és alkalmazzanak. Jó példái ennek az elbürokratizálódott nagy testületek. A politikai-adminisztrativ rendszer (az egyes európai országoké, de az Európai Közösségé is) a magasabb komplexitás iránti igényre mindeddig inkább a hierarchiákat elönyben részesitő stratégiájával válaszolt. Következménye a mind több elöirás, a szükségest messze meghaladó számú formális és ténylegesen müködő hierarchiaszint, valamint a növekvő bürokrácia lett (Maurer, J. 1995).

A fizikai hálózatalkotáson túlmenően a közlekedési rendszerek hagyományosan is hierarchikusan épültek fel, mégpedig a településstruktúrával összefüggően. A teljesítmény és területi funkció tekintetében, továbbá összeköttetési rendszerében több hierarchikus szintet alkotó vasủt után a közúti közlekedés is mind erốsebben hierarchizálttá vált a településeket elkerülö, illetve kikerülö autópályák épitésével, amelyeken kétszer akkora sebesség érhető el, mint a szokásos úthálózaton.

A közlekedés hierarchizáltságának a jövőben várható mértéke kedvezötlen tényezö lehet a területfejlesztésben. Azzal a ténnyel kell szembenézni, hogy a hagyományos közlekedésnél jóval kedveltebb, forgalmukat jobban növelö autópályák, nagysebességü vonatok és légi vonalak hálózata ma a hierarchia legelsó szintjén lényegesen ritkább, mint a távolsági utak vagy a vasúti fövonalak hálózata volt egykor. Ezért igénybe vételük lehetősége meglehetősen kevés kedvezményezett helyre korlátozódik. (Felhajtóágak az autópályákon gyakran 15-20 km-enként, nagysebességú vasutak megállóhelyei 100-200 km-enként, interkontinentális közlekedésre berendezkedett repülöterekböl csak mintegy tíz van Európa "magterületén", és alig húsz egész Európában stb.)

\section{Gyakorlati problémák}

\section{Az európai városhálózat hierarchizált szerkezetének problémái}

a) A városhálózat szélsöségesen hierarchizált szerkezetének veszélyei, megavárosok kialakulásának lehetõsége

A hierarchiák és hálózatok közötti feszültségek Maurer J. (1995) szerint nagytérségi szinten a következő szcenáriók közüli választás lehetőségében nyilvánulnak meg:

- A koncentrált közlekedési beruházásokkal elősegített vertikális szervezödéssel, hierarchikus struktúra érvényesülésével az európai kontinens gazdasági, kulturális, tudományos és politikai életét néhány - tízmilliós nagyságrendü világváros (London, Párizs, esetleg Berlin) uralja. Ezekben a megaagglomerációkban találhatók majd a fontos döntési központok. A többi városrégió az elöbbiek által meghatározott hierarchiának rendelödik alá. A me- 
zögazdaság iparosodottságára (kevés munkaeröigényére) is visszavezethetöen, így azután nagy és meglehetősen "üres" vidéki tẻrségek növelik a kontrasztot; a területi fejlôdés minden tekintetben szélsôségesen alakul.

- Horizontális szerveződéssel az európai városok sokrétú hálózata megmarad, a meglévõ városrégiók fejlödnek a sajátos (egyedi minőségü) kultúrtájukból és gazdasági potenciáljukból táplálkozva, és válnak a városrégión túli tevékenységek számára kialakult különbözö hálózatok részévé. A közlekedési beruházások lehetövé teszik a hálózatok sokaságát és sokrétüségét, valamint a megfelelö nagyságú regionális piacokat. Ezáltal erősödik Európa régióinak önállósága és egyedi jellege.

Nem lehet kétséges, hogy az elsỏ szcenárió ellentmond Európa sokféleségének (mint egyik értékének), ezért a területfejlesztés által az összeurópai érdekek alapján is elutasítandó. Sajnálatos azonban, hogy e változatnak megfelelő törekvések tettenérhetők Európa gazdasági, közlekedési, söt regionális politikájában és az esetleges "szupermetropoliszok" fejlesztésének, fenntartásának szándékában is.

A szélsőségesen hierarchikus városhálózat létrejötte Maurer J. (1995) szerint különösen a szükebb értelemben vett Közép-Európa kilátásait tenné kedvezötlenebbé. E térség részei (Dél-Németország, Elzász a Rhône-Alpok régió, Észak-Olaszország, Ausztria nyugati része és Svájc) nem képeznek szerves gazdasági-politikai egységet, de van néhány közös jellemzőjük. Többek között az, hogy a kontinensen belül a leggazdagabbak közé tartoznak. A közép- és kisvállalatok, valamint a "jövőt hordozó" modern gazdasági húzóágazatok aránya itt magas. Régóta nemzetkőzi irányultságúak és sokféle kisebb és néhány kiterjedtebb hálózattal rendelkeznek. KözépEurópa kultúrája az egyéni kezdeményezés, az önálló cselekvés, a felülröl és kiviulröl érkezö befolyások elleni kemény ellenállás értékein alapul. Az Európa más részeivel, sót a világgal kialakult sokirányú kapcsolat ellenére a lakosság többsége a legerösebben és legbensöségesebben a saját településéhez és régiójához, illetve a számára kedves, nagy értékeket hordozó tájához kötődik. Itt a területi szerkezet számos olyan városra épült, amelyek a területi hálózatok kisebb csomópontjai. Ellenben egyetlen régió sincs ebben a kiterjedt térségben, amelyben elég késztetés lenne a "szupermetropolisz" nagyságrend küszöbének átlépéséhez a jövöben. (Sem Milánó, sem Bécs vagy München fejlödése nem vezethet oda.)

Ehhez társul a realitásokon alapuló gondolkodás, valamint a hatékony, pragmatikus cselekvés képessége, amely számol Európa sajátos területi fejlődésével, a korlátozott erőforrásokkal és Kelet-Közép-, valamint Kelet-Európa sürgősen megoldandó problémáival.

$\mathrm{Az}$ elóbbi értékei, tulajdonságai alapján éppen Közép-Európának áll érdekében elutasitani a városok esetleges új (szélsőséges) hierarchiáját. Ez a magatartás azonban a Közösség adminisztrativ központjától, Brüsszeltöl való kritikus távolságtartással és a hivatalos európai politika kritizálásával is jár, mert az eurokraták nagyon erösen a szupermetropoliszokra, valamint ezek összekötésére és multinacionális vállalatok igényeire koncentrálnak, miközben a települések és régiók sokrétü hálózatának nem szentelnek elég figyelmet, annak ellenére, hogy szlogenszerủen fennen hirdeti a "régiók Európáját".

E politika következményeként a sürün települt "ballungok", agglomerációk tovább koncentrálódhatnak (pl. néhány "szupermetropolisz" kialakulása, illetve továbbfejlödése által) és így a városrégiók finoman tagozott hálózata gyengülhet. 
Ennek folyamán a szabadidó eltöltést szolgáló különféle üdülóhelyek környezeti terheltsége veszélyes állapotot érhet el, és végsö soron csökken a lehetösége annak, hogy a sürün és ritkán lakott vidékek egymást funkcionálisan kiegészitsék - az egymáshoz való viszonylag közeli fekvés elönyét kihasználva. Egy ilyen helyzet következményeként ma még alig elörebecsülhető költségek keletkezhetnek a környezetszennyezés miatt.

A kommunikációs technológiák fejlödése nyomán végbemenő gazdasági és politikai változások a várható tendenciájuk alapján a régi és új államhatárok gazdasági jelentőségét csökkentik. A létrejövő "időintegrált" világrendszerben a kiterjedtté vált városi agglomerációs térségek a nemzetközi kommunikációs hálózatok csomópontjaivá válnak és a korábbiakkal ellentétben nem csupán a környékük, illetve hátterük központjai, hanem országok közi, söt globális hatókörhöz is jutnak. Ez a hatókör növekedés pedig a fö közlekedési vonalakat vonzó hatásával az európai föhálózat térszerkezetének alakulására, közvetetten pedig a regionális fejlödés differenciálódására döntö hatással lehet.

b) A kiegyensúlyozottabb városfejlödés lehetösége a reálfolyamatok alapján

A megavárosok kialakulásának, egyoldalú növekedésének és Európa városhálózatát erősen torzító, szélsőséges aránytalanságokhoz vezető hatásának víziója azonban az urbanisták egyes köreiben már jóval árnyaltabb nézetté "szelídült". İgy pl. $P$. Hall (1998) szerint Európa városainak fejlödése komplex és ellentmondásos módon megy végbe. Több településkategóriában, illetve típusban mutatkozik fejlödés, de nem általánosan.

- A kiterjedtebb agglomerációk és nagyvárosok mérsékeltebb továbbfejlödésének esélyei

A nagyvárosok továbbfejlödésének bizonyos esélyeit a legtöbb urbanista arra az új jelenségre vezeti vissza, hogy a globalizáció és az információs gazdaság korszakában a nagyvárosok kiemelkedően fontos (esetenként meghatározó) szerephez jutnak a hatékony közvetlen információcserében és a fizikai közlekedésben is. (Ezekben találhatók a legrangosabb csomópont repülőterek és a nagysebességü vasutak pályaudvarai és itt futnak össze az ingázók személyközlekedési áramlatai.)

A nagy sürüségü térségek, agglomerációk növekedése valójában tovább tart. Ez a megállapítás azonban a nyugat-európai, központi elhelyezkedésú metropoliszrégiókon (Londonon és a körülvevő DK-Anglián, Párizson és az Ile-de-France-on, a hollandiai Randstadton) kívül Európa más régióinak politikai és gazdasági központjaira (pl. Koppenhágára, Milánóra, Madridra) is érvényes.

Végső soron azonban ez a folyamat tételesen nem mond ellene a megaváros keletkezés (már idézett) teóriájának, azonban a kompakt óriásvárosok helyett azok területileg kiterjedtebb, jórészt lazább szerkezetűvé váló változatával számol. Még fontosabb e folyamat eredménye funkcionális szempontból, nevezetesen, hogy az újabb keletü posztindusztriális gazdasági tevékenységek igen erösen a legnagyobb agglomerációs térségekben (konurbációkban) összpontosulnak, de oly módon, hogy a velük kapcsolatos munkahely-nyereség föként a kủlső gyürüben és még inkább az agglomerációt körülvevő bolygóvárosokban mutatkozik meg. 
Az európai városrendszer legfelsőbb szintjén belül eddig éles kontraszt mutatkozott:

- egyfelöl az előbbiekben tárgyalt (nagyteljesitményủ és sủrủ légi, nagysebességú vasúti és telekommunikációs összeköttetésekkel behálózott, illetve felfüzött) metropolisz régiók sủrủ clusterje, és

- másfelöl néhány központi területen levő "gateway" funkciojú, vagy "regionális főváros" között, amelyek ugyan milliós vagy több milliós nagyvárosok, de nincs meghatározó pozíciójuk Európa városhálózatában, még ha fontos szerepet töltenek is be földrészünk térszerkezetének alakulásában.

A földrész szinten európai léptékben kapu szerepet betöltỏ gateway városok az. utóbbi időben nagyon dinamikusan fejlödnek:

- többnyire interkontinentális légi vonalak végpontjai és ezáltal a globális szolgáltatások széles palettáját kínálják, föleg azokban az esetekben, amikor egy egész nyelvterület számára meghatározó szerepkörrel rendelkeznek. (Mint pl. Madrid a spanyol nyelvú latin-amerikai országok, Lisszabon a portugál nyelvú Brazília és afrikai országok, Róma a jelentős amerikai és más földrészekbeli olasz etnikum, Marseille a frankofon afrikai országok számára stb.);

- némelyek pozícióját már a nagysebességủ vasúti hálózati indulópont (illetve leendő csomópont) funkció is erôsíti, amelyek révén ma még szolidabb, a jövőben azonban (a bövülö hálózat eredményeként) már jelentősebb mértékben képesek az országhatárokat messze átlépó interakciókat vonzani (Hall, P. 1998).

\section{- A középvárosok}

Jellegzetes kategóriáját alkotják az európai városoknak a "tartományi fỏváros" rangú, kiterjedt vidéki térségekben nagy vonzáskörzettel rendelkező (nagyjából félmillió lelket számláló), a városhierarchia magasabb középszintjét alkotó "középvárosok" (Bristol, Hannover, Bordeaux, Bologna stb.), amelyekben magasabb szintủ közösségi szolgáltatások (felsőfokú oktatási, egyetemi orvosképzési háttérrel támogatott egészségügyi stb.) sora, rangos kereskedelem, nagy idegenforgalmi vonzerö összpontosul. Közülük néhány a csúcstechnológiai ipar központja, vagy éppen kiterjedt területre decentralizált irodai (részben táv-) munkahelyek hálózatba szervezéséböl (is) profitál.

A városhierarchia alsóbb középszintjét elfoglaló (negyedmilliósnál kevesebb népességü) "megyei/kerületi székhelyek, azaz a közepes nagyságú igazgatási- és szolgáltatási központok (amelyek Európa vidéki térségeiben százszámra találhatók), ugyancsak általában fejlődóképességükröl tanúskodnak, amit a helyi-térségi szolgáltatási központként való növekvő jelentöségüknek köszönhetnek. Gyakran azzal hívják fel magukra a figyelmet, hogy különlegesen kedvező (természeti, kulturális) környezeti feltételeket nyújtanak lakóhelyként való igénybevételükhöz, ezért mind a beköltözőkre, mind a külfooldi tókebefektetőkre rendkívül erós vonzeröt gyakorolnak, és a lehetö legideálisabb összhangot igyekeznek megteremteni a közlekedési, energiaellátási és lakóhelyi funkciók között.

\section{- Kisvárosok}

Európa meglehetősen kiegyensúlyozott urbanizációs fejlődésére utal, hogy a városhierarchia alsó szintjén elhelyezkedő kisvárosi térségek is növekednek (népességben és foglalkoztatásban), mégpedig lényegesen gyorsabban, mint az óriásváro- 
sok. Ez a folyamat tetten érhető a legnagyobb és legsürübb nagyvárosi agglomerációk (a londoni, a Randstad deglomeráció) külső övezeteiben, de a nagytérségi decentralizáció folyamatába is beilleszkedik, azaz a világvárosokból körkörösen kifelé, a távolabbi vidéki térségekbeli városokba való áttelepüléshez vezetve.

Nyugat-Európa számos országának közepes- és kisvárosaira azonban kétségtelenül sok esetben nem az endogén, önerejủ és öntörvényủ fejlödés a jellemzö, hanem szinte kizárólag a nagyvárosokból eredỏ spill-over hatásokból profitálnak, funkcionális értelemben vett (bár urbanisztikai értelemben már csak a távolabbi elhelyezkedésük miatt sem annak minősülő) "kvázi bolygóvárosokként".

\section{- A korridorvárosok különleges vitalitása}

Tapasztalati tények igazolják, hogy a közlekedési korridorok markáns városfejlödési tengelyeket képező hatása egyáltalán nem csupán a jövöre érvényes teoretikus feltételezés, hanem már létező, kézzel fogható jelenség. Az eddigi magisztrális közlekedési pályakötegelödések (többnyire folyóvölgyekben egymás mellett vezetö vasúti fővonal, autópálya, vízi út, csővezeték, nagyteljesítményủ távolsági optikai távközlési kábel) igencsak intenzív városodási folyamatot inditottak el, pl. a Mannheimtöl D-re eső Felső-Rajna völgyben (a Rajna alsóbb szakaszán már a két világháború között megvalósult a korridor), vagy a Lyon alatti Rhône-völgyben, de ide sorolható az olaszországi Emilia-Romagna tartomány is. Ezekben az esetekben (és túlnyomóan a többi esetekben is) egyértelmüen spontán fejlỏdés vezetett a közlekedési folyosók kialakulásához. Néhány esetben (mint pl. Délkelet-Angliában) tudatos területpolitikára alapozott tervezés produkálta ugyanezt a jelenséget - amelyet a város- és területfejlesztők többsége kedvező következményekkel járónak tart. Hall, $P$. (1998) szerint megegyeznek a vélemények arról, hogy ez a forma, azaz a nagyfontosságú közlekedési tengelyek mentén elhelyezkedő sokfunkciós kisvárosok clusterje feltehetően a városfejlődés leginkább fenntartható formáját képviseli, ezért e fontos szerkezeti elemet egyes állami terulletfejlesztési stratégiákba is átvették mint pl. az Egyesưlt Királyságban.

- A policentrikus fejlesztési idea alkalmazásának lehetöségei az egyes városkategóriákban

Az európai szintü területfejlesztési konceptus napjainkban gyakran hangsúlyozott alapelve a decentralizált koncentrációval kialakítható policentrikus rendszer kialakításának szükségességét húzza alá (Hall, $P$. 1998). Ezt az elvet nemzeti szinten több országban már régen a területi tervezés alapjává tették. Ilyen elvek alapján igyekeznek már régóta Hollandiában a gazdasági fejlỏdést a túlterhelt Randstadból más, "lazább" területekre átterelni.

A policentrikusságra törekvés tartalma, illetve jelentösége térségi szintek és földrajzi kontextusok szerint különbözik. Nemzetközi szinten a policentrikus fogalom az alternatív globális gazdasági hatalmi centrumok fejlödésével kapcsolatban merül fel.

Európában kétségtelenül csak néhảny olyan metropolisz található, amelyek világméretekben is rangos ellenörzö- és irányító központok: London minden tekintetben, Párizs némely szempontból ennek minősül. Nehezen túlértékelhetố körülmény azonban, hogy földrészünkön egy egész sor "szubglobális" város is van, amelyek bizonyos téren globális funkciókat látnak el: Róma (kultúra), Milánó (divat), Zürich és Frankfurt (bankélet), Brüsszel, Luxemburg, Párizs, 
Róma és Genf (szupranacionális kormányzati szervezetek terén). E szinten a policentrikus politika elsősorban arra irányul, hogy néhány tevékenység a globális világvárosokból áthelyezỏdjön a fogadóképes szubglobális városokba. Ezen felül azonban a kérdésnek térbeli fekvésbeli, az európai területszerkezetet érintő dimenziója is van: e szubglobális városok közül sokan (habár nem valamennyien) az európai központi elhelyezkedésủ metropolisz régión kivül fekvõ (többé-kevésbé periférikus) országok politikai vagy gazdasági fôvárosai. Ezekhez tartozik Helsinki, Stockholm, Koppenhága, Berlin, Bécs, Róma/Milánó, Madrid/Barcelona, Lisszabon és Dublin. Itt mindenekelőtt az a kérdés merül fel, hogy kívảnatos-e a decentralizált tevékenységeket csupán néhány olyan "regionális fövárosra" - Így Koppenhágára, Berlinre, Rómára, Madridra - koncentrálni, amelyek funkcionális hatása a közösségi terület jelentös részén érvényesül, vagy hogy nem lenne-e ésszerübb ezeket a tevékenységeket az országfövárosok között (beleértve a kisebb országok fóvárosait is) megosztani.

Alacsonyabb szinten persze a policentrikus fogalom (illetve a többközpontúságra törekvés) a városok valamennyi kategóriájából (részben az agglomeráció peremiekból, részben vidéki térségekbeliekből) való vándorlásokhoz is kapcsolható.

E folyamat a legnagyobb méretekben valószínüleg London térségében megy végbe, ahol London város mára egy 30-40 alcentrumból álló, $150 \mathrm{~km}$ sugarú rendszer központjává vált, miközben (más történelmi okok miatt) Párizs és Berlin térségében csak viszonylag gyengén fejlett várostömörülési rendszer alakult ki. A következő szinten néhány városnál, mint Stockholm, Koppenhága és Milánó, ugyancsak széles körü elvándorlási folyamat figyelhetô meg, miközben ez a jelenség ugyanennek a szintnek más városaira már nem jellemző. $P$. Hall (1998) szerint ezen a szinten a policentrikus fejlesztési elvet a lehetőség szerint nagy méretekben a decentralizált koncentráció stratégiájára kell alapozni, a folyamatot azonban bármikor lehetséges néhány kiválasztott közlekedési korridorra irányítani, beleértve a nagysebességü vasúti korridorokat is. (A kvázi nagysebességủ, azaz 160-200 km/óra sebességủ pályák Stockholm és Koppenhága számára már hamarosan rendelkezésre állnak, belátható időn belül Londont is elérik, de London-Ashford, Amszterdam-Antwerpen vagy Berlin-Magdeburg viszonylatokban is lehet számítani a létrejöttükre.)

A félreeső, periférikus vidéki térségekben a világvárosoktól és szubglobális városoktól távolabbi helyeken a policentrikus fejlesztési szempont további dimenziót nyer. Itt a 200-500 ezer lakost számláló "regionális fóvárosok" (Bristol, Bordeaux, Hannover, Ravenna, Zaragoza) és a kisebb, 50-200 ezer lakosú "megyei fővárosok" potenciálját kell erösíteni.

\section{C./ A TEN nem kívánatos területi hatásai}

\section{a) A kritika szempontjai és célpontjai}

Nehéz megnevezni olyan közismert innovációkat, illetve innovativ rendszereket, amelyekrỏl előbb-utóbb nem derül ki, hogy nem kívánatos hatásaik is lehetnek. Ez alól nem kivétel a TEN sem.

A TEN-nel szembeni - némelykor bizonyos szkepszist is érzékeltető - kritika részben a közlekedési ellátottságban mutatkozó területi differenciálódás megfordíthatatlanságára, a közlekedési elérhetőség és feltárás, mint területfejlesztő tényező szerepének korlátosságára, de legfóképpen a TEN területi koncentrációhoz vezetö folyosóhatásaira hivatkozik, megkérdöjelezve a TEN jelenlegi formájának a periférikus térségek felzárkóztatására való alkalmasságát (Klimke, U. 1996).

Nem felejthetö hiányossága a TEN-nek, hogy az 1980/90-es évek elején meghirdetett alapelvekkel szemben a késỏbb kidolgozott programjaiban az elvárhatónál 
nagyobb mértékben szerepel a nagysebességủ szárazföldi hálózat, különösen a környezeti szempontból legjobban kifogásolható közúti közlekedés. Erre az egyoldalúságra bizonyos mértékig magyarázat lehet a just in time termelési/szállitási módszerek elterjedése, amely növeli a közúti szállítás iránti általános igényt. E módszer alkalmazói többségükben a fỏutakhoz közeli cégek, amelyek a legjobban élvezni tudják a gépkocsik rugalmas közlekedéséből származó előnyöket. A termelés ésszerúsitése, az üzemi költségek csökkentése szempontjából korszerú logisztikai módszert tehát a közúti közlekedés "kontójára" alkalmazzák, mivel végsö soron csak tovább súlyosbítja a fcrgalomtorlódásból eredő gondokat a már eddig is ettöl szenvedö tengelyek menti térségekben, korridorokban (Erdmenger, J. 1996).

A kifogásolható alágazati szerkezet tervezöi az EU egyes központi országaiban, illetve a kohéziós országokban az útépitéseknek biztositott erős prioritással figyelmen kivül hagyták a nyilt tengeri, a part menti és a rövid távú tengeri hajózásban (mind a szállitási teljesitmény, mind a környezetvédelem terén) rejlö lehetőségeket, föleg az Atlanti-óceáni és a Földközi-tengeri térségekben. Pedig ezek igénybevételére már most szükség lenne. Félő ugyanis, hogy a későbbiekben kialakítandó kikötők, illetve a majdani vízi-közlekedési összeköttetések nem képesek jól funkcionáló hálózattá összekapcsolódni és megszabadítani a szárazföldi közlekedési útvonalakat a forgalmi torlódásoktól. A tengerihez hasonlóan a hagyományos vasúti közlekedés és a belvizi hajózás sem kapott megfeleló szerepet a TEN-röl hozott döntésekkor.

\section{b) A periféria problematika}

Az Európai Unió területpolitikai törekvéseinek középpontjában a periférikus térségek megkülönböztetett módon és gyorsasággal való fejlesztése, felzárkóztatása áll az ún. kohéziós politika keretében, amelynek a fejlettségbeli kiegyenlítődéshez, vagy legalábbis a közlekedéshez kell vezetnie (Lutter, $H$. 1995). E törekvésnek több motivációja is van: az összetartáson (a belső kohézión) kívül elsősorban a rideg tény, hogy Európa a globális versenyben nem mondhat le perifériáiról, még pontosabban az ottani erőforrásokról, mert a fejlett nyugat-európai magtérség eröi önmagukban nem sok esélyt adnak a világ többi erőközpontjaival (Észak-Amerikával, a Távol-Kelettel) folytatott kemény gazdasági harc megvívásához. Ugyanakkor Európa sokszínúségének, mint relevanciájában növekvő értéknek a fenntartására is szükség van, nem szabad, hogy veszélyeztesse a kohéziós folyamat (Towards... 1997).

Mielött azonban a TEN-nek a perifériákra gyakorolt hatását elemeznénk, szükségesnek látszik a többértelmủ periféria fogalom "körbejárása", az egyes szakágitudományi értelmezések bemutatása.

- A periféria fogalom többféle értelmezése, a központi területek fogalma

A "területi (földrajzi) periféria" fogalom jelentését a korunkbeli politikai és technológiai változásokkal összefuiggésben kell értelmezni. Háromfajta perifériát különböztetünk meg:

- a (nemzetközi- és nemzeti) politikai értelemben vett perifériát (amely a gazdasági-politikai rendszere miatt általában elmaradott, illetve amely a "politikacsinálás", döntéshozatal központjaitól messze fekszik), a földrajzilag félreesö, kontinens peremi helyzetủ területeket, 
- a nagy hálózatokhoz nem csatlakozó ("csatlakozáshiányos") területeket, amelyek egyúttal túlnyomórészt gazdasági perifériák is, azaz elmaradottabbak.

A kőzlekedési hálózathoz csatlakozás szempontjából az európai perifériákhoz egy sor olyan (hegyvidéki, szigeti fekvésú, illetve "leköszönő" müszaki struktúrájú) terület tartozik, melyek nagyságukban és tulajdonságaikban egymástól eltérnek, és amelyek kohéziójának megteremtése különféle intézkedéseket igényel. Európa centrumtérségei alatt ezzel szemben olyan városias, sürün települt és lakott területek, agglomerációk értendők, amelyek valamennyi közlekedési eszkőz hálózatával össze vannak kötve.

A perifériákkal ellentétes "gazdasági tekintetben központi helyzet" tehát egyre kevésbé a geometriai értelemben vett központi fekvést, hanem inkább azt jelenti, hogy az ilyen területröl állandóan elérhetők a megfelelő kapcsolat révén a stratégiai jelentőségủ tudományos információk, bekapcsolódtak az ismeretek nemzetközi áramlásának pályáiba, és hogy az információkat, a tudásalapanyagot képesek feldolgozni, ez teszi lehetővé az új versenyképes gazdaság megalapozását, a saját belsỏ adottságaik jobb kihasználását.

- A periféria helyzet kimutatása az agglomerációkhoz való térbeli viszony alapján

A perifériális és a központi elhelyezkedés gazdasági dimenziónak meghatározásához az adott térségeknek a jelentős európai agglomerációktól, mint központoktól való távolsága a mérték.

Egészen leegyszerüsítve azok a települések képezik a tágabb értelemben vett agglomerációs térséget, amelyekből a legkőzelebbi agglomerációs centrum egy órán belül elérhetỏ. Ezek - más régiókhoz képest - központi helyzetben vannak, és lehetővé teszik az ott mükődő gazdaságnak az agglomeráció elönyeiből való közvetlen részesedést (Viegas, $J$. 1998).

Periférián levőnek közlekedési szempontból és európai léptékben egyes nyugati területfejlesztési iskolák azt a régiót tekintik, amelyból az agglomeráció centruma 3 óra oda-vissza utazással nem érhetó el. Még a légi közlekedés (mint a leggyorsabb közlekedés) figyelembe vételével is sok terület van Európában, amely kivül esik ezen a 3 órás határon.

- A perifériák leszakadásának irányzata a közlekedésben és a beruházásokban

Az utóbbi évtizedekben tett erőfeszitések ellenére a közlekedési infrastrukturális beruházások a perifériákon elmaradtak az európai átlagtól. A versenyképesebb központi térségekben müködő cégeket gyakran a szállítási lehetöségek elégtelensége és a kis népsürüség miatti drágasága tartja vissza attól, hogy a nehezen elérhető periférikus és ultraperiférikus térségekben beruházzanak.

\section{c) A TEN koncentráló, a területi különbségeket növeló hatásai}

A kritika abból indul ki, hogy a tervezett transzeurópai közlekedési hálózat a ritkasága és a peremterületeken való gyenge jelenléte miatt aligha éri el eredeti célját, nevezetesen a periférikus régiók megközelíthetöségének, ezáltal versenyképességének javulását. Ezt az igényt azonban már csak az ágazati és a területi politika érdekellentétei miatt sem egyszerü kielégíteni. 
- A közlekedéspolitika (az ágazati érdek) és a területpolitika (a regionális érdek) alapvetố célkonfliktusa a hálózat sürüsége és a vonalak megvalósításának idöbeli sorrendje tekintetében

Ágazati szempontból azok a közlekedési beruházások kivánatosak, amelyek gyors megtérülését nagyfokú kihasználtságuk biztositja. Ezt a követelményt legjobban a nagy termék-kibocsátású, ezáltal erős forgalmat gerjesztő és gazdaságilag dinamikusan fejlödö központokat összekötő, intenzív vonalvezetésủ vonalak képesek kielégíteni. Közlekedéspolitikai és -gazdasági megfontolásból tehát azok a beruházások az ésszerüek, amelyek a legnagyobb méretủ szállitási szükségletekre irányulnak. Így a fejlesztések azokon a kỏzlekedési fötengelyeken összpontosulnak, amelyeken a forgalom-áramlások már amúgy is intenzívek. $A$ közlekedéspolitika ezzel kedvez a ritka magisztrális hálózatok létrejöttének, illetve továbbfejlödésének és az olyanfajta hatásainak, amelyek a dinamikus régiók javára válnak. Ez gyakorlatilag azt jelenti, hogy mivel a TEN kiépitésének nincs időbeli ütemezési programja, így fennáll a veszélye annak, hogy elöször a leggyorsabb megtérülést igérő legnagyobb korridorok épülnek meg, amelyekhez aránylag a legkönnyebben elöteremthetök a beruházáshoz szükséges összegek (Vickerman, $R$. 1995).

A spontán fejlödés mellett eddig a deffenziv európai közlekedéspolitika is ott segíti elő a közlekedési infrastrukturális beruházásokat, ahol a forgalomáramlás már amúgy is igen intenzivv, de szük keresztmetszet mutatkozik az infrastruktúrában, hegység vagy tengerszoros lassítja az áruk és személyek mozgását. (Pl. a Csalagút, a dán/svéd szorosok híd/alagút rendszere, az új alpesi alagutak és a pireneusi átjárók.)

Az ágazati érdekkel ellentétben a területfejlesztés kardinális szempontjából, nevezetesen a kiegyenlittődés érdekében sürübb, a területek közlekedési feltárására alkalmasabb hálózatra lenne szükség. A TEN hálózat besủrítése viszont (a forgalom egyenetlen megoszlása miatt) megnehezíti, vagy éppen lehetetlenné teheti a gazdaságos üzemeltetését. Ezért ragaszkodnak a tervezők a ritkább és hierarchikusan erösen tagolt, a magisztrálékat preferáló hálózathoz.

A TEN magisztrálékhoz és a kiegészitö hálózatokhoz füzödỏ érdekek ellentéte a multinacionális és a kisvállalatok között a piacuk szállitási igényei alapján

Az Európát átfogó összeköttetésekkel és együttmüködésekkel kapcsolatosan a különbőző társadalmi rétegek, gazdasági érdekcsoportok részéröl felmerüló valamennyi kívánság természetesen nem teijesíthető. A TEN létrehozása elsősorban a nagy agglomerációkhoz kötỏdó multinacionális vállalatok érdeke, akik igen nagy piacokra és az ahhoz szükséges infrastruktúrákra orientálódnak, ezért standardizálnak, automatizálnak és csak kevés munkaeröt igényelnek. (Ezért a foglalkoztatási gondok enyhítése nem várható töluk.) Ezzel szemben a közepes és kisvállalatok a regionális léptékü piacokra utaltak, ezért elsösorban jó regionális közlekedési rendszerekre van szükségük. Mindenekelött ezek a vállalatok teremtenek új munkahelyeket, képesek enyhíteni a foglalkoztatási gondokat. Az öntudatosabb polgárok pedig egyszerúen nem akarják a regionális önállóságot gyengíteni, pláne feladni; ezért a TEN hálózathoz kapcsolódásért nem rajonganak (Viegas, J. 1998). 
A TEN lehetséges szerepe a telephely-választásban és a foglalkoztatásban, illetve a területi fejlödés differenciálásában

- A posztindusztriális fejlódési modellre alapozó, a korridorok menti növekedéssel nem számoló felfogás

A szkeptikusok egyik csoportja a termelési telephely-választás szempontjából ad helyet kételyeinek arra hivatkozva, hogy a régiók vagy országok közötti (makroléptékú) helyválasztásnál a teherszállítási lehetőség, mint befolyásoló tényezö háttérbe szorul, és a "puha" kritériumok kerülnek elötérbe. A gazdasági eredmény szempontjából fontosabb "nem termelö tevékenységek" nagyobb keresletet támasztanak a gyorsabb, széleskörü területi kapcsolat megteremtésére lehetőséget biztositó személyközlekedés, mint az áruszállítás iránt. A nagysebességủ személyszállitás viszont érezhető mértékü munkahelyteremtéshez a folyosók mentén nem vezethet, hanem inkább kevesebb, de értékesebb új munkahely keletkezéséhez a személyszállitás nagy központjaiban, mint pl. repülöterek vagy a szupervasutak nagyvárosi pályaudvarai mellett.

E teória szerint végső soron a korridorok mentén nem, hanem csak az általuk öszszekötött nagy központokban lesz tetten érhető a TEN növekedést elősegítő hatása.

- A hagyományos szemléletü, a "szivattyúhatások" miatt erös térbeli koncentrációtól tartó felfogás

Mások viszont hagyományos szemlélettel attól tartanak, hogy a magisztrálék igen erös vonzó ("szivattyú- és alagút") hatással lesznek a termelési tényezökre, és ezáltal differenciálják a területi fejlődést.

A régió- és országhatárokon át megvalósuló jobb elérhetöség a magisztráléktól távolabb fekvő térségek "kiüresítésével" $P$. Hull (1998) szerint kedvezötlen "szivattyúhatást" vonhat maga után:

- a gazdaságilag erősebb területek (gyengébb) hảttértérségei kiterjedtebbé válnak, a ritka hálózaton belüli "lyukak" belsejében levő területek kiüresedö zónákká lesznek, ami kedvezőtlen népesedési folyamatokban is megnyilvánulhat;

- a hátrányos helyzetú vidéki, elmaradott térségekben megépülö új infrastruktúra révén a fejlett régiók gazdasági szereplöi könnyebben hozzáférnek a perifériák erőforrásaihoz, így elönytelen versenyfeltételek mellett végbemehet a kiaknázásuk.

A nagysebességü, a hagyományosnál jóval ritkább hálózatok a lineáris közlekedési és gazdasági koncentráció, fővonalak menti fejlődési folyosók kialakulásának veszélyét hordozzák magukban. Ezek "alagúthatást" gyakorolhatnak, ami a befektetöket eltántoríthatja attól, hogy a fỏhálózattól kétoldalt távolabb fekvỏ müszakilag/forgalmilag alig kapcsolódó területekre települjenek.

- Az európai közlekedésben már ténylegesen végbemenõ és a TEN korridorok mentén várható koncentráció hatásai a periférikus térségekre

A már ma tetten érhetỏ reálfolyamatok igazolják az elméleti feltételezéseket, miután egész Európában a különféle közlekedési alágazatok területi összpontosulásának lehetünk a tanúi (EUROPEAN Spatial... 1997). A légi közlekedésben a más 
földrészekkel való összeköttetést föleg az EU központi területén müködő nagy repưlöterek látják el. A menetrendszerủ interkontinentális járatoknak az északnyugateurópai nagy repülôtereken (Párizs, London, Frankfurt, Amszterdam, Koppenhága stb.) való koncentrációja tovább erôsödik (Erdösi 1996a). A tengeri kikötők között is erốs koncentrálódási folyamat megy végbe: az interkontinentális tengeri összeköttetések - a légi közlekedéshez hasonlóan - ugyancsak Európa ÉNy-i részén összpontosulnak. A Rotterdamot, Antwerpent, Amszterdamot, Hamburgot mind jobban a többi kikötő fơlé emelő differenciálódás egyik legfontosabb tényezöje a hozzájuk csatlakozó, a kombinált szállítást lehetővé tevö, a kontinens belsejét mélységében feltáró belvízi utak (Rajna, Schelde, Északi-tengeri-csatorna, Elba) teljesítöképessége (Erdôsi 1995a,b).

A legfrissebb tapasztalatok (pl. a francia TGV, a német ICE nagysebességú vasutakkal és jó néhány autópályával kapcsolatban is) arra engednek következtetni, hogy a TEN korridorok a legtöbb esetben markáns gazdasági fejlódési tengelyekké válhatnak - különösen konjunktưra idején a kevésbé fejlett országokban, így Magyarországon is (Erdösi 1996b). (Többek között erre utal Székesfehérvár növekedése, amelynek lakossága a helyi foglalkoztatási lehetőségek révén dinamikusan növekszik az amúgy csökkenó népességú Magyarországon.)

Máris - extrapolálható - tapasztalati tény, hogy az autópályák és a nagysebességü szupervasutak létrehozása a fejlett, nagy sürüségủ térségekben (agglomerációkban és nagyvárosokban), valamint az azokat összekőtő korridorok egyes részein válnak különleges fejlesztõ erővé. Ezzel a már régóta tartó koncentrációs irányzat erösődhet.

Ma még részleteiben tisztázatlan, hogy a jövöbeni nagysebességủ hálózatnak milyen nagyságrendú központokban lesznek a megállói. Ezeket nyilvánvalóan nem csak a lakosságszám, hanem a gazdasági erő, a struktúrától is fưggő mobilitási igények alapján kell meghatározni. Az teljesen nyilvánvaló, hogy a nagysebességü vasút a drágasága, egyéb rendszertulajdonságai, a gazdasági követelmények miatt csak a nagy központok, agglomerációk intenziv összekötésének lehet az eszköze, amelynek nagy forgalomra kell berendezkednie. A nagysebességủ vonatokról joggal feltételezhető, hogy tovább növelik a Közösség központi területeinek elónyét azzal, hogy megvalósul az egymástól távoli metropoliszok közötti utazás idejének 4 óra alá szorítása.

Jóllehet, a Transzeurópai Hálózatok 14 elsőbbséget élvező projektje közül öt a négy kohéziós országban található, a projektek nagy többsége az EU gazdaságilag jobb helyzetben levõ központi térségeiben valósul meg, azok helyzetét még kedvezöbbé teszi.

A TEN magisztrálék ugyan általában kedveznek a nagyobb városoknak, azonban e tekintetben a fejlesztö hatás árnyaltabban prognosztizálandó, mivel komoly különbségek állhatnak eló a nagyvárosok között a hálózattól való távolságuktól függöen.

A legnagyobb nyereségre azok a városok tehetnek szert, amelyeknek eddig alig volt valami esélyük a nemzetközi nagyteljesítményü hálózathoz való kapcsolódásra. Ez tulajdonképpen a kedvezőtlen földrajzi helyzetben levő kohéziós országok (Spanyolország, Portugália, Görögország, Írország) bizonyos városaira (pl. Lisszabonra, Athénre) jellemző. 
A legtöbb fenntartással a területtudományok a TEN-nek a periférikus térségekben (hivatalosan) várt fejlesztő szerepével szemben vannak. Egyre nyilvánvalóbbnak látszik, hogy a rendkívull drága, nagyteljesítményú közlekedési eszközök, különösen a nagysebességü vasút aligha lehet a gyérebben lakott periférikus területek kiszolgálásának, illetve a "magterületek"-kel (agglomerációkkal) való közlekedési kapcsolatok megteremtésének eszköze, tehát nem tudja a gyéren lakott területeket közelítően egyenlő mértékben bekapcsolni.

A TEN fejlesztési eszközöknek a korridorokra koncentrálódása oda vezethet, hogy a félreeső régiók elérhetósége, közlekedési helyzete - legalábbis viszonylagosan rosszabbodik, imázsuk is romlik.

A perifériákkal ellentétben a központi régiókban az új pályaépítések általi idömegtakarítás összességében kevesebb, ennek ellenére e megtakarítások gazdasági hatásai a nagyobb piacok és a népsürüség miatt erösebbek mint a perifériákon. Végsỏ soron tehát a TEN nagysebességú hálózata elmélyítheti a területi különbségeket.

- A perifériák közlekedési elérhetőségének javitásából származó elônyök viszonylagossága

Az elóbbiekben ismertetett kételyekkel szemben a legtöbb elemzésben abból a feltételezésböl indulnak ki, hogy a TEN kiépitése a perifériák elérhetőségének javulásához vezet, amely a közlekedés összköltségét csökkenti, ezért gazdasági hasznot hoz létre (EUROPA 2000+1994, Die künftige Entwicklung 1993; HIGHSPEED EUROPE.. 1995). Ezek a szimplifikált feltevések azonban alapos átgondolásra, sót felülvizsgálatra szorulnak.

Elöször is körüultekintésre van szükség az elérhetöség árának és következményeinek mérlegelésekor. Az elérhetőséget javitó, tökéletesített kőzlekedés a sebesség növelésével nyilvánvalóan csökkenti az utazási idöt. Ez önmagában azonban még nem igazán közvetlen gazdasági haszon, hacsak az időmegtakarítást nem lehet költség-megtakaritássá átváltani. A hatalmas összegekbe kerülö infrastruktúrafejlesztéseket a közlekedőknek valószínüleg magasabb pályahasználati viteldijakkal kell megfizetni. İgy a fejlesztéssel elért menetidő rövidítésnek (egy bizonyos határon túl) inkább csak a szükséges jármüállomány csökkentésében és más közvetett ·következményekben lehet jelentősége. (Pl. a közlekedés megbízhatóságának javulásában.) Ezért a cégek talán hajlandóak magasabb átlagos díjakat fizetni a jobb szolgáltatásokért.

Másodszor az elérhetôség javitása nem biztos, hogy a megcélzott kedvezményezett térségben fejti ki a fejlesztõ hatását, elöfordulhat, hogy ennek más területek veszik a hasznát.

Így pl. a periférikus régiókra irányuló fejlesztések e területeket, mint piacokat az olyan expanziv, nagy tókeerejủ és keresett árukat gyártó vállalatok számára teszik hozzáférhetővé, amelyek a központi régiókban mükődnek. Ezek terjeszkedése miatt nem tudnak kellöen érvényesülni a helyi termelök a perifériák piacain. Végsó soron tehát a hálózat kedvezỏ hatása a perifériákra nem a várt mértékben érvényesül, jóval gyengébb lehet, mint az eleve kedvezöbb helyzetú központi térségekre. Ezt a folyamatot elösegítheti a termelés méretgazdaságossági okok (economies of scale) miatti koncentrációja. A közlekedésfejlesztések hatékonyságát a termelés szállításigényes- 
sége is befolyásolja. Nagy értékủ, kis tömegü áruk termelése esetén a periférikus, illetve elmaradott térségekbeli közlekedés-fejlesztéseknek kevés a hozama.

Számításba veendő az is, hogy még, ha az elérhetőség javítása szállítási költségcsökkenést és termelésnövekedést is eredményez, ez nem szükségszerüen vezet az anyagi jólét megjelenéséhez az adott területen lakók körében. A termelés decentralizálása ugyanis nem zárja ki a termelés irányitásának, ellenôrzésének további összpontositását a központi térségekben. Ez az ellentmondásos szerkezet pedig ezért fenntarthatja vagy növelheti a területi különbségeket a jövedelmek terén.

Összegezö tanulságként megállapithatjuk, hogy

- Az egyik legnagyobb feladat az "alagút-effektus" és a "szivattyú-effektus" kiküszöbölése. Itt a közlekedés intelligenciájába (pl. elektronikus irányításába) való befektetésnek lehet a nagyobb hozama.

- Önmagában a közlekedési feltételek, az elérhetőség javítása egyetlen szinten sem garancia (periférikus) területek, a települések fejlödésének. (Viszont a nem kifejezetten periférikus fekvésü, hanem csupán viszonylagos elszigeteltségü térségek gazdaságai a nem éppen kedvezö közlekedési helyzetük ellenére sok esetben képesek életben maradni, megörizni viszonylagos pozíciójukat.) Gazdasági növekedési folyamat csak akkor indul meg a hátrảnyos helyzetũ területeken, ha a jobb összeköttetések, a fejlettebb infrastruktưra más (helyi) hatótényezők sikert ígérō kombinációjával (illetve az elmaradott térségek termelési környezetének fejlesztésével, korszerübb szerkezetúvé alakitásával) járnak együtt. Ezért a beruházásokról hozandó döntési folyamatban azt is vizsgálni kell, hogy ezek a "kiegészíto" tényezök léteznek-e, mert csak a megfelelö érvényesülésük esetén van esély a közlekedési beruházások számottevőbb térségi hatásaira.

- Az EUTEK (Európai Területfejlesztési Koncepció) Noordwijkben elfogadott vázlatos elképzelése éppen úgy, mint az 1998. áprilisi berlini összeurópai EUREK-konferencia és az EU más dokumentumai is síkra szállnak a többközpontú területfejlesztés mellett. Ennek nemcsak a regionális kohézió számára lehet kedvezó következménye, hanem az EU globális versenyképessége számára is abból a megfontolásból, hogy ha a perifériákat nem sikerül bevonni teljes értéküen az európai gazdasági fejlödésbe, akkor Európa lemondhat a meglévö eröforrásainak kb. a felérōl, tehát jóval kisebb esélyekkel, nem eléggé kreatívan tud csak részt venni a globális piacokért folytatott versenyben. Európa nagy értéke a sokarcúsága, amelyre, mint kiaknázandó, kedvezỏ tulajdonságára a fejlesztók gyakran hivatkoznak. Ez a valós potenciál azonban csak akkor érvényesülhet, akkor válhat gazdasági erôvé, ha a különbözö területek feltárása és hatékony hasznosítása megvalósul.

\section{A TEN nemkívánatos regionális hatásai mérséklésének lehetöségei a területpolitikóval összhangban levő közlekedésfejlesztés feladatai}

A TEN-nek a területi fejlődés szempontjából kedvezötlen hatásai kivédésére, illetve mérséklésére elvileg alkalmas lépések, intézkedések köre széles, azonban egyenként nem, hanem csak összekapcsoltan és együttesen képesek eredményeket hozni. 
- A térségek közlekedési problémáit nem lehet egyedül a mobilitási lehetöségek körének bövitésével, az elérhetőség javitásával megoldani. A területek jobb elérhetöségén kivül az infrastruktúra hatékonyabb és fenntarthatóbb módon való használatára, e két feltétel együttes biztositására is szükség van, amihez a tudás és az innovációs képesség legszélesebb körủ jelenléte kell, hogy párosuljon. A fenntarthatóságnak és a közpénzek ésszerú müködtetésének a kettős követelményét érvényesitő politika nagyobb hangsúlyt helyez a multimodális megoldásokra és más, a már meglévő infrastruktúra még hatékonyabb kihasználására alapozó lehetöségekre.

- A közlekedésfejlesztés módjait a föbb területtípusoknak megfelelöen kell meghatározni.

A sürün települt agglomerációs térségekben a kisebb helyigényủ és környezetbarát villamos üzemü vasút preferálása célszerü a közúti és légi közlekedéssel szemben, mégpedig a logisztikai központokkal kiegészülö multimodális szállítási rendszerek keretében. Ahol a természeti feltételek lehetővé teszik, a vízi szállítás lehetöségeit is fokozottabban igénybe kell venni (Erdősi 1995a). A közlekedés alágazati szerkezetének alakításában rejlö lehetőségek kimerülése esetén további megoldást kínál a szállítási szükségletek mérséklése egyes szállitásigényes tevékenységek áttelepitésével. Ebben az esetben olyan stratégiákra van szükség, amelyek a közlekedésre, környezetre, terủlethasználatra és regionális fejlesztésre vonatkozó, a fenntartható mobilitást elösegítő ésszerüsítő elveket egyeztetett módon egyaránt magukba foglalják.

A ritkán települt, részben földrajzilag peremhelyzetü, de egyszersmind gazdasági értelemben vett perifériának is számító térségekben gazdaságossági okok miatt a magisztrális hálózat sürítése csak ritkán célravezető. $E$ helyett a néhány magisztrálé elérési pontjai számának növelésével, a hozzájuk csatlakozó másodlagos hálózatok kialakításával lehet a területek közlekedési feltárását egyenletesebbé tenni, illetve a helyi sajátosságoknak megfeleló technika alkalmazásával modernizálhatók a regionális közlekedési szolgáltatások. (PI. egyszerüsített üzemelésü hagyományos vasutakkal, ahol pedig még ezek sem gazdaságosak, ott busszal.) A viszonylag kis utasforgalmat generáló, ritkán lakott térségeknek a sürün települt, fejlettebb központi térségekkel való távolsági összeköttetésére a drága (és rosszul kihasználható) nagysebességü vonatoknál és autópályáknál alkalmasabb a regionális légi közlekedés. Kiváltképpen a szigetek kohéziója szempontjából lehet különleges jelentősége a légi kapcsolatnak és a közlekedési szükségletek egy részét feleslegessé tenni képes korszerü távközlésnek (Erdősi 1998a).

- Biztosítani kell a TEN kedvezó hatásainak egész Európában való érvényesülését. Ehhez a tervezett teljes hálózat, valamint a még nem tervezett kiegészítö/regionális (forgalomráhordó/szétosztó) hálózat kiépítésére van szükség.

- A közlekedési rendszerek közötti jól müködő helyettesítés/kiegészités szempontjából fontos tényezőnek tekinthetô az országos, a regionális és a helyi szolgáltatások egybehangolása. (Ez különösen fontos a ritkán lakott területeken, ahol a hiányzó összeköttetések - legyenek azok infrastrukturális vagy szolgáltatás jellegủek -, még mindig problémát jelentenek.) Lényeges, hogy 
a hálózatok között a különböző szinteken hatékony összeköttetések alakuljanak ki. Pl. egy új regionális közlekedési szolgáltatás két kisebb város között képes elösegíteni azok országok közötti (nemzetközi) elérhetőségét is.

- A régiók elérhetősége nem javítható csupán az Európán belüli kapcsolatok alapján, mert érvényesülnie kell az interkontinentális szempontnak is (Erdösi 1998d). Európa kikötói és repülöterei más világrészekkel való öszszeköttetéseiben mutatkozó szembeötlő különbségek csökkentése (a repülöterek forgalmának irányszerkezetében végrehajtandó megfelelő módosításokkal, illetve a fö tengeri kikötők funkcionálisan összehangoltabb európai hálózatának megteremtésével) minden régiónak az érdekében állna, legyen az a központban (ahol a közlekedésbeli torlódások súlyosbodásának egyik fö oka a forgalomáramlás kiegyensúlyozatlansága), vagy pedig valamelyik távol fekvő periférikus területen.

\section{D./Összefoglaló következtetések}

A kontinensünk keleti felére kidolgozott Páneurópai Hálózatokkal szemben a TEN nem komplex hálózat, hanem csupán az egyes közlekedéshordozók magisztráléi Európára kidolgozott alágazati hálózatainak ősszessége, mintegy "gyüjteménye". Mindegyik alágazat igyekszik a maga fontosságát és a területfejlesztésben betöltött eminens szerepét bizonyítani az alágazati dokumentumokban, projektgyủjteményekben. Lassan egy évtizede lesz, hogy a részprojektek ismertté váltak, de még nem került sor az integrált összeurópai közlekedésrendszer (komplex korridorrendszer) területfejlesztési szempontokat érvényesitoó, a lehetséges következményekkel számoló, átgondolt és valóban egyeztetett kidolgozására (Erdősi 1998c).

Egyenlöre a TEN program végrehajtása meglehetősen illuzórikusnak tünik több szempontból is:

- időarányosan (1998-ig) rendkivil kevés valósult meg az alágazati hálózati tervekből, de a kiemelt fontosságú projektek kőzül is inkább csak azok realizálódtak, melyeket, mint eredetileg a TEN-töl független, korábbi vállalkozásokat "beemeltek" a TEN keretébe (pl. dán tengerszorosok híd/alagút komplexumait, a TGV vonalak néhány irányban való meghosszabbitását),

- nem sok jele van annak, hogy a környezetvédelem alapvetõ szempontként érvényesülne, mivel a liberalizáció hatására a modal splitben változatlanul tart a közúti közlekedés térnyerése a vasúttal és a belvízi hajózással szemben, és alig valósult meg valami a rövid vonalakon folytatott "regionális" légi közlekedés nagysebességü vonatokkal való helyettesítéséből. Sőt, a regionális légitársaságok forgalma töretlenül növekszik az egymástól csupán 150-300 km-re levó várospárok közötti vonalakon is, holott az európai közlekedéspolitika határozott célja, hogy az $500 \mathrm{~km}$-en belüli viszonylatokban ott is átterelódjön a menetrendszerú légi közlekedés a vasutakra, ahol nincs nagysebességü vasút, ahol van, ott viszont $800 \mathrm{~km}$-en belül felesleges a környezetet jobban terhelö repülögépek (a légtér kapacitásának nagy részét kimerító módon való) használata (Erdősi 1996a). Egyenlöre az európai polgárok túlnyomó többsége szemében mindjobban leẻrtékelődnek a lassúbb kőzlekedésre alkalmas pályák és eszközök (a nemzetkőzi, a nagytávolsági közlekedési vi- 
szonylatok arányának növekedésével, a futárszolgálatok iránti igényekkel stb.), mikőzben a legtöbb ember még nem eléggé fogékony a környezeti problémák iránt, vagy ha felismeri is a közúti közlekedés további térnyerésének veszélyét, saját kényelmét minden más szempont fơlé rendelve másoktól vár megoldást, de az önmérsékletre a mobilitás terén alig hajlandó. Ezért nem valószínü, hogy az EU döntéshozói által kitüzött nagyszabású tervek az elképzelt "környezetbarátibb" alágazati szerkezetben megvalósulnak, mert a közlekedö-szállító/szállíttató polgárok környezeti tudata elmarad attól a szinttöl, amikor már - akár anyagi áldozatvállalás és kényelmének bizonyos mértékü feladása árán is - hajlandó az egyéni közlekedéssel szemben a kőzhasználatú közlekedést elönyben részesíteni. Nagyon valószínủ, hogy az egyes személyek tudatára apellálás nem teszi feleslegessé a váltásra késztető intézkedéseket, pl. az externáliák internizálásával az egyéni közlekedés lényeges drágítását (Erdôsi 1997b).

- A térségi koncentrációs folyamatot a TEN magisztráléi elösegitik és a terület-politikai intervenciók legfeljebb csak mérsékelni képesek a "szivattyú" és "alagút" effektust. (Számolni kell a multi- és szupranacionális vállalatok érdekérvényesítésével, a periférikus térségekbeli érdemi fejlesztések késésével és korlátozott anyagi lehetóségükkel, ugyanakkor a fejlett, sürübben települt kőzponti térségekbeli korridorok elsők kőzötti és energikus fejlesztésével.)

\section{Irodalom}

Die künftige Entwicklung der Gemeinsamen Verkehrspolitik. Globalkonzept einer Gemeinschaftsstrategie für eine auf Dauer tragbare Mobilităt. - Bulletin der Europăischen Gemeinschaften, Beilage 3/93. - Kommission der Europäischen Gemeinschaften Brüssel-Luxembourg 1993. 82 o.

Erdmenger, J. (1996) Transeuropăische Netze im Bereich Verkehr. - EUREG, 3. 6-10. o.

Erdősi F. (1995a) A belvizi közlekedés folldrajza. (Ágazati és regionális kommunikáció-fóldrajz l.) JPTE, Pécs, 208 o.

Erdősi F. (1996a) A légi közlekedés földrajza, légiközlekedés-politika I-II. kötet. - Kézirat, MTA RKK Pécs, 7500.

Erdősi F. (1997a) A magyarországi közlekedési infrastruktúra regionális jellemzôi változásának szükségessége az európai uniós tagság elnyerésével. - Kézirat (készult az Integrációs Stratégiai Munkacsoport számára), MTA RKK Pécs, 61 o. (Megjelenik az Európai Tukơr - Mühelytanulmányok sorozatban.)

Erdősi F. (1995b) A tengeri közlekedés földrajza. (Ágazati és regionális kommunikáció-földrajz II.) JPTE, Pécs, 174 o.

Erdősi F. (1998b) A Transz-és Páneurópai hálózatok. (A kozlekedés szerepe az Európán beluli kohézió erősitésében és a fejlettségbeli kiegyenlitődésében.) - Kézirat, MTA RKK Pécs, 32 o. (Megjelenik a Kulpolitika c. folyóiratban.)

Erdösi F. (1997b) Altalános kommunikáció-földrajz. - Egyetemi jegyzet kézirata. Pécs, 205 o.

Erdősi F. (1998d) Az új transzeurázsiai vasúti összeköttetések. - Kézirat, Pécs, Megjelenik a Kozlekedéstudományi Szemlében.

Erdősi F. (1998a) Európa közlekedése és területfejlódése - Kézirat, MTA RKK Pécs, 2500.

Erdősi F. (1994) Európa kozlekedésének "fordítókorongja" az Alpok. - Tér és Társadalom, 1994. 1-2. 186-209. 0 .

Erdősi F. (1998c) Európa közlekedési nagyszerkezetének orientációs változása. - Kézirat, Pécs, Megjelenik a Földrajzi Értesítőben.

Erdösi F. (1996b) Magyarország kommunikációs tengelyeinek alakulása. - Tér és Társadalom, Raumentwicklung EG - Regionalpolitik. - Europäische Kommission. - Brüssel-Luxembourg 1994.

EUROPA 2000+ (1994) (Europaische Zusammenarbeit bei der Raumentwicklung). EG Regionalpolitik. - Europăische Kommission, Brussel-Luxembourg 
EUROPEAN spatial development perspective. First official draft. Informal meeting of Ministers responsible for spatial planning of the member states of the European Union. - Noordwijk, gand 10 June 1997 (E.S.D.P.)

Hall, P (1988) Motoren des globalen wirtschaftlichen Weltbewerbs. - Elöadás németre fordított szovege. Sokszorosítva az "Auf dem Weg zu einer gesamteuropäischen Politikstrategie" - c. EUREKkonferenciára. Berlin, 1998. április 27.

HIGH-SPEED EUROPE, (High Level Group "The European High-Speed Train Network") - Office for Official Publications of the European Communities, Brussels-Luxembourg 1995.

Klimke, U. (1996) Verkehrspolitik im zusammenwachsenden Europa. - Zeitschrift für Verkehrswissenschaften, 66-75. o.

Kunze, E. (1995) Österreichs Gestaltungsspielraum Transeuropaische Netze. - RAUM 20. 37-39. o.

Lutter, H. (1995) Entwurf für einen optimierten Verkehrsträger - Mix. [Transeuropåische Netze] RAUM 20. sz. 33-38. o.

Maurer, J. (1995) Neue Aspekte transeuropaischer Netze auf der Sicht Zentraleuropas. - Kézirat, elóadva valamelyik vasúti kongresszuson C-sitzung 2: Heuptentwicklungs-achsen: Die Rolle der transeuropäischen Netze 43-48. o.

TOWARDS A PAN-EUROPEAN TRANSPORT NETWORK. Report on adjustuments to crete corridors. - Brusseles, 1/10/97.

Vickerman, R. (1995) Restructuring of transport networks. - Előadás kézirata, Prága, 1995. október 16.

Viegas, J. (1998) Verkehr und Telekommunikation-Weitweite Kommunikation und răumliche Anbindung. - Elöadás németre fordított szóvege. Sokszorosítva az "Auf dem Weg zu einer gesamteuropäischen Politikstrategie” - c. EUREK-konferenciára, Berlin, 1998. április 28.

\section{THE IMPACT OF THE TRANS-EUROPEAN NETWORKS TO THE SPATIAL DEVELOPMENT}

\section{FERENC ERDÓSI}

The article aims at addressing the issue of the Transeuropean Network (TEN) and Paneuropean Network (PEN) and their impact on regional economic development in Europe. The chief goal of this study is to highlight the fact that these developments, in reality, are not in tandem with those affects which are ,officially" planned by policy-makers. Perhaps, the most significant problem with TEN and PEN is the fact that a complex plan, including the most important principles of spatial development, for developing European transport networks has not been produced yet. The lack of this plan cannot be substituted by the existing documents which outline 7 development principles for TEN and the 10 complex transport corridors and 4 highpriority transport areas for PEN. The other great challenge is how to handle those regional inequalities between regions which are close to the transeuropean corridors and those located further from them, which come to life after the transeuropean networks are in place. There seems to be a danger that national and European regional policies cannot resolve but can only alleviate these inequalities. 